\title{
Reform in Accounting Teaching in Application- oriented Universities and Colleges in China: A Survey on Accountant's Structure and Quality of Small and Micro-sized Enterprises
}

\author{
CHEN Zi-ni, XU Qi-hui, ZHENG Bo* \\ School of Business, Eastern Liaoning University \\ Dandong, Liaoning, P. R. China \\ Zhengwave1964@163.com
}

\begin{abstract}
China were investigated. It turns out that the accountants in these enterprises had received lower education, low professional titles and limited knowledge. They were not skilled in accounting computerization and not good at accepting new technology and knowledge. They were mainly occupied in basic work such as billing and making up bills. Most of them were incapable of taking part in the business forecast, decision and planning of the enterprises. Accordingly, in the education of application-oriented universities and colleges, courses of financial accounting should be reduced and those of management accounting and statistics should be increased. Besides, courses of comprehensive quality and new technology should also be added.
\end{abstract}

Keywords-Application-oriented university and college; Accounting teaching; Small and micro-sized enterprise; Accounting talents

\section{INTRODUCTION}

In China, the small, micro-sized, home workshop style and privately of individually-owned business are generally called small and micro-sized enterprises. Specifically, it refers to an agriculture and farming enterprise with annual income no more than 5 million yuan; an industrial enterprise with fewer than 300 employees and annual operating income less than 20 million yuan; and a catering enterprise with fewer than 100 employees and operating income less than 20 million yuan. Presently, there are more than 12 million small and micro-sized enterprises in China, accounting for more than $90 \%$ of all the total enterprises [1-3]. They have become a fresh troop for economic development, a main channel for employment and an important resource for innovation. They play an important role in stabilizing growth, enhancing employment, promoting innovation and meeting the various demands of people. The state pays high attention to these enterprises because they concern the overall economic and social development.

Nevertheless, these enterprises lag behind large mature enterprises in management system, talent allotment and capital. On the other hand, most graduates of accounting specialty in application-oriented universities and colleges will get jobs as accountants in these enterprises; therefore, how to make the graduates fit the requirements of the enterprises is a key reference for the universities and colleges. In this study, a survey on the structure and quality of 151 accountants in 121 small and micro-sized enterprises was conducted. The main imperfection of the accountants was found and accordingly some suggestions as to improving the teaching of accounting specialty in application-oriented universities and colleges in China are proposed.

\section{STRUCTURE AND QUALITY OF ACCOUNTANTS IN SMALL AND MICRO-SIZED ENTERPRISES IN CHINA}

200 questionnaires were sent to accountants in 121 small and micro-sized enterprises in 12 cities in Liaoning province and 151 valid questionnaires were received. The results were counted and listed in table 1 and table 2.

*Corresponding author 
TABLE I THE STRUCTURE OF ACCOUNTANTS IN SMALL AND MICRO-SIZED ENTERPRISES (SURVEYED ACCOUNTANTS: 151)

\begin{tabular}{|c|c|c|c|}
\hline Structure type & Specific index & Accountant number & Proportion/\% \\
\hline \multirow[t]{5}{*}{ age } & under 25 & 16 & 10.60 \\
\hline & $25-30$ & 21 & 13.91 \\
\hline & $30-40$ & 45 & 29.80 \\
\hline & $40-50$ & 42 & 27.81 \\
\hline & more than 50 & 27 & 17.88 \\
\hline \multirow[t]{5}{*}{ specialty } & accounting & 50 & 33.10 \\
\hline & Financial management & 39 & 25.80 \\
\hline & Auditing & 12 & 7.90 \\
\hline & Tax revenue & 11 & 7.30 \\
\hline & other & 39 & 25.83 \\
\hline \multirow[t]{5}{*}{ Educational background } & $\mathrm{PhD}$ & 7 & 4.64 \\
\hline & Master & 17 & 11.26 \\
\hline & undergraduate & 63 & 41.72 \\
\hline & junior college & 51 & 33.77 \\
\hline & other & 13 & 8.61 \\
\hline \multirow[t]{4}{*}{ Professional title } & Senior accountant & 18 & 11.92 \\
\hline & Accountant & 36 & 23.84 \\
\hline & Junior accountant & 41 & 27.15 \\
\hline & Purse bearer & 56 & 37.09 \\
\hline
\end{tabular}

It can be seen from table 1 that most accountants are aged form 30 to 50 , accounting for $57.61 \%$ of all the accountants. This shows that these enterprises have a reasonable age structure of accountants. But the $17.88 \%$ accountants older than 50 have outdated knowledge, are reluctant to receive new knowledge and techniques and do not work efficiently. In respect to specialty structure, there are 50 accountants who are originally majored in accounting, accounting for $33.1 \%$ of all surveyed people, while there are 62 people majored in accounting-related majors such as financial management, auditing and revenue, with a percentage of $41.06 \%$. There are more than a quarter accountants have no background of accounting education. This shows that a majority of accountants had received education fitting in with their occupation, while the percentage of non-professional accountants is quietly big. In respect to educational background, there are 24 accountants have an education level higher than master degree, accounting for $15.9 \%$ of all the surveyed people; there are 63 accountants have university education background, accounting for $41.72 \%$; while 64 accountants have not received undergraduate education, accounting for $42.38 \%$. Those with low education background can hardly keep up with the fast development of accounting techniques. More than 40 percent enterprises express that the educational level of accountants is so low that can not meet the demands of development. Besides, there only 18 accountants have high professional titles, accounting for $11.98 \%$; there are 36 accountants have middle titles, accounting for $23.84 \%$. Nearly two-third accountants have primary professional titles, showing that the accountants in small and micro-sized enterprises mainly work on basic financial accounting such as keeping and cast accounts. Most of them are unable to participate in the business forecast, decision, planning and control.

Meanwhile, the professional quality of the accountants in small and micro-sized enterprises was also surveyed. The content included the understanding of accounting standard and rules, the application of financial software and the knowledge and usage of the Internet and big data. The results are listed in Table 2. 
TABLE II PROFESSIONAL QUALITY OF ACCOUNTANTS IN SMALL AND MICRO-SIZED ENTERPRISES (SURVEYED ACCOUNTANTS: 151)

\begin{tabular}{|c|c|c|c|}
\hline Professional quality & Specific level & $\begin{array}{c}\text { Accountant } \\
\text { number }\end{array}$ & $\begin{array}{c}\text { Proportion } \\
1 \%\end{array}$ \\
\hline Understanding and & Very familiar and flexibly using & 32 & 21.19 \\
\hline & Basic understanding & 86 & 56.95 \\
\hline $\begin{array}{l}\text { accounting standards and } \\
\text { rules for small and micro- } \\
\text { sized enterprises }\end{array}$ & $\begin{array}{l}\text { Keep accounts only and no understanding of the } \\
\text { standards and rules }\end{array}$ & 33 & 21.85 \\
\hline \multirow[t]{3}{*}{$\begin{array}{l}\text { Computerization and use of } \\
\text { financial software }\end{array}$} & $\begin{array}{l}\text { Complete computerization, be able to use financial } \\
\text { software proficiently }\end{array}$ & 31 & 20.53 \\
\hline & $\begin{array}{l}\text { Mainly dependent on manual keeping accounts, } \\
\text { simply use financial software }\end{array}$ & 94 & 62.25 \\
\hline & $\begin{array}{l}\text { Keep accounts manually and no use of financial } \\
\text { software }\end{array}$ & 26 & 17.22 \\
\hline Understanding and & Be able to master and use & 11 & 7.28 \\
\hline application of new & Have certain understanding & 45 & 29.80 \\
\hline $\begin{array}{l}\text { technologies such as the } \\
\text { internet and big data }\end{array}$ & No understanding and use & 95 & 62.91 \\
\hline
\end{tabular}

It can be seen from Table 2 that the professional quality of the accountants is unsatisfactory. More than half accountants know little about the accounting standards and rules, and nearly $22 \%$ of them do not know them at all. What they do is just processing transactions mechanically but they do not know why it is done. Only about one-fifth of the accountants can skillfully use financial software; 94 accountants, accounting for $62.25 \%$, do their work manually only with financial software as an assistant. There are 26 accountants, accounting for $17.22 \%$, keep accounts completely manually. Besides, there only very few young accountants are interested in the new technologies such as the Internet and big data, more than $90 \%$ accountants are indifferent to and unfamiliar to those, let alone application in practice.

In summary, the prominent problems of small and microsized enterprises are lower education level and professional titles, which lead to the deficient theoretical knowledge, slow computerization popularization and disability to receive new knowledge and techniques.

\section{THE WAY TO REFORM ACCOUNTING TEACHING IN APPLICATION-ORIENTED UNIVERSITIES AND COLLEGES IN CHINA}

\section{A. The necessity for accounting teaching reform}

In China, the personnel cultivation objective of accounting specialty in regional application-oriented universities and colleges was formulated in the middle and late period of the 20th century, which was designed to train personnel for enterprises and public institutions with basic knowledge and skill of accounting, management and law. The job orientation of the graduates is mainly the positions of small and microsized enterprises. Concerning the economic environment and technical condition, the main duty of an accountant is to check computation; accordingly, business accounting was regarded as the priority when formulating curriculum and teaching content. The emphasis was laid on the accounting skills and standard principles. More class hours were given to courses such as accounting foundations, financial accounting, cost accounting and integrated accounting simulation to train student's basic skills of keeping account, calculating and submitting expense accounts. The state issued policies to encourage the training model with priority of skill and standardization. Students are encouraged to obtain skill certificates by examination. With such a target orientation, accounting techniques and methods were over-emphasized in teaching and students were busy in obtaining various certificates. As a result, students were only able to keep account and computation and did not know the whys and wherefores. They did not know that the essence of accounting was to serve the management of the enterprises and were unable to serve the management of the enterprises with accounting data [4-7]. The drawback of this training model has been reflected in the survey. It is proved that this model has not adapted the demands for the abilities of accountants in the new era; therefore, it is imperative to reform the present training model, curriculum and teaching content. 


\section{B. The way to reform the accounting teaching}

New requirements have been raised for accountants. A bookkeeper who can only keep accounts, calculate and process data is no longer qualified. The accountants an enterprise needs are those can use new knowledge and techniques to serve the management of the enterprise [8]. The adjustment of accounting teaching may carried out in aspects as following.

1) Reducing the courses of financial accounting

Traditionally, financial accounting courses, such as accounting foundations, primary financial accounting, intermediate financial accounting, advanced financial accounting, cost accounting, tax accounting, integrated accounting simulation, etc, account for excessive proportion and class hours in the curriculum. All of them are courses to train student's skill of financial accounting and should be reduced.

2) Strengthening the teaching of management accounting and statistics

Increase the class hours of management accounting and enterprise internal control courses and cancel the course of integrated accounting simulation. Add the course of management accounting practice. Besides, it can also be considered to add courses of enterprise strategic planning and risk analysis so as to strengthen the content of management accounting. Meanwhile, the class hours of courses related to mathematical statistics should be increased to adapt to the application of big data in the Internet times.

3) Adding courses of comprehensive quality and new technology

With the transition of accountant's duty from calculation to management, an accountant with just accounting skills will not be qualified. They must improve their comprehensive quality to serve the operating management of the enterprise [9-10]. Therefore, courses such as economics, management science, basic economic law, composition, accounting culture and accounting ethics may be added. Besides, in order to improve the ability of using new knowledge and techniques, courses such as e-commerce, Internet finance, Internet transaction process, financial software development and application of network may also be added.

\section{CONCLUSION}

The personnel training objective and curriculum of regional application-oriented universities and colleges must have timeliness and flexibility. Because they have no obvious change for years, the accounting teaching lags behind the scientific development and accounting practice. Therefore, the specialties in these universities and colleges must adjust and reform the teaching so as to remain invincible in the wave of technological revolution.

\section{ACKNOWLEDGMENT}

This paper is supported by Educational Science Planning Project of Liaoning Province (JD15DB137).

\section{REFERENCES}

[1] Z. Y Yu. "Accountant employees in small and micro-sized enterprises: Problems and countermeasures" (In Chinese). Management and Scitechnology of Small and Middle Enterprises, issue 8, 2014, pp92-93.

[2] Q. S. Zhong. How to give full play of accountants in small and microsized enterprises (In Chinese). Accountant, issue 14, 2012, pp76-77.

[3] Y. K.Du, F. Song. "A study on accounting of small and micro-sized enterprises” (In Chinese). Business Accounting, issue 12, 2013, pp 165166.

[4] Z. X.Zhang, X. Yang, M. Xin. "Professional positions of accountants with application of AI in accounting" (In Chinese). China Journal of Commerce, issue 30, 2016, pp168-169.

[5] [2] X. J. Su, R X Yang, X. T. Yang. "AI education system design based on big data" (in Chinese). China Science and Technology Information, issue 23, 2017, pp 52-55.

[6] W. L. Dong. "AI drives accounting future" (In Chinese). New Financial Management, issue 1, 2018, pp42-45.

[7] M. Gao. "Effect of AI on accounting profession" (In Chinese). China Journal of Commerce, issue 3, 2018, pp147-148.

[8] J. Yang. "Challenge and strategy of accountants face in financial robot times" (In Chinese). Chinese Market, issue 1, 2018, pp183-184.

[9] W. Sheng. "Challenge and countermeasures of AI development on accounting". Accounting Learning, issue 10, 2018, pp. 99.

[10] W. Z. Wang. "Present situation and countermeasures of college students under AI" (In Chinese). China University Student Career Guide, issue 2, 2018, pp10-12. 